\title{
Note from the Editor
}

This special issue of East Asian Science, Technology, and Medicine, guestedited by Michael Stanley-Baker (Nanyang Technical University, Singapore) addresses "Religion and Science in China", a major issue in the historiography of Chinese science.

The Chinese, Japanese and Korean languages have one common feature: in all three languages, the modern words for 'science' (科學, Ch. kexue, J. kagaku, K. gwahag) and for 'religion' (宗教, Ch. zongjiao, J. shūkyō, K. jonggyo) are recent creations, originating in Japan. This fact should provide us with a valuable hint that, when dealing with the pre-modern age, these words represent observers' categories rather than actors' categories. On the other hand, the historiography of East Asian science has been structured by the perceived necessity to prove, against Eurocentric prejudice, that China (as well as Korea and Japan) is as worthy as Europe of appearing in histories of science - that proof being, it seems, forever dismissed or simply ignored by those who continue to produce a historical narrative of 'science' confined to the European continent. The tension between these two features, namely the imperative of historicizing the objects we are working on and the need to legitimize them, has underlain many of the historiographical debates of the last few decades. Rather than resolving this tension, historians of science, technology and medicine who study pre-modern East Asia have learnt to work with it.

The present special issue presents the strategies of a new generation of scholars (all three of them have obtained their PhDs in 2012-2013) to study the interactions between the complex historical phenomena that the words 'religion' and 'science' refer to. It comes as no surprise that digital humanities are an important tool here: indeed they enable studies to span an unprecedentedly large quantity of sources, and, sometimes, to produce quantified arguments and to shed light on changes over longue durée.

Michael Stanley-Baker proposes a historiographical discussion, in which he shows that the now frequently used term 'Daoist medicine' (daojiao yixue 道教醫學) is a neologism that only came into use in the 1990s. He argues that this term covers up, rather than accounts for, the complex historical phenomena relating to the organization and transmission of curing practices. He then goes on to discuss the ways in which drawing on Science and Technology Studies enables one to bring out the processes by which certain medical practices came to be claimed as 'Daoist'.

Stephan Kory also starts from a term, but one that is indeed found in pre-modern sources, namely zhanhou 占侯, which he traces through a wealth of sources of the first millennium CE. He thus shows that zhanhou 
refers to a historically variable set of mantic practices. It developed as a term that could refer to a variety of techniques that involved scrutinizing qi, through the observation of heavenly and earthly phenomena, in order to predict human fortune. These techniques were practiced both in court and in other social milieus. As well as a set of practices, the author characterizes zhanhou as a form of applied cosmology, and as such, a vector of transmission of worldviews.

Jonathan Pettit's contribution focuses on the representations of sacred lands by early medieval Daoist writers, and especially on Tao Hongjing's 陶弘景 (456-536) commentaries on Han dynasty descriptions of temple lands that were then being recreated on behalf of royal patrons. Pettit brings to light the claims as to who may or may not legitimately occupy ritual space and its surroundings that underlie Tao's geography.

These three articles, which together provide a glimpse of the state of the field of studies of religion and science in early and medieval China, are followed by six book reviews.

Catherine Jami

CNRS

Chine, Corée, Japon (UMR 8173, CNRS \& EHESS) 